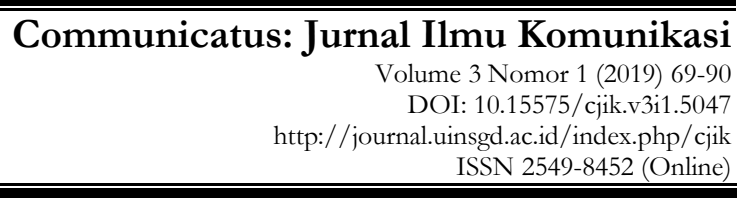

\title{
Public Relations Politik Partai Keadilan Sejahtera dalam Pemilukada Jawa Barat
}

\author{
Khoiruddin Muchtar ${ }^{1 *}$, Aliyudin ${ }^{2}$ \\ ${ }^{12}$ UIN Sunan Gunung Djati Bandung \\ *email: khoiruddin@uinsgd.ac.id
}

\begin{abstract}
The research aims to obtain an overview of the media relations of the Prosperous Justice Party in building party image, determining strategies in maintaining positive relations with the media, and utilizing social media in forming the opinions of candidates for governor of West Java in 2018. Research uses constructivist paradigms, qualitative approaches and case study methods. The results of the study show that, political public relations within the Prosperous Justice Party are carried out by building togetherness and consolidation as well as cadre formation in a family and equality manner. Communication within the Prosperous Justice Party began to be addressed and conditioned, especially the spread of information within the PKS. PKS external communication is carried out by building a positive image of the party, building coalitions with other parties, and socializing the characteristics of West Java governor candidates so that they can be accepted by the community. The imaging strategy carried out by the Prosperous Justice Party in the media is done by building good relationships with the media and utilizing social media appropriately as well as utilizing E-mail, blogs, social media or Twitter. PKS vote acquisition as runner-up in 2018 West Java Pilgub shows, the existence of PKS as a party that is quite trusted and calculated.
\end{abstract}

Keywords: Strategy, Public Relations, Pemilukada, Partai Keadilan Sejabtera

\begin{abstract}
ABSTRAK
Penelitian bertujuan untuk memperoleh gambaran tentang media relations Partai Keadilan Sejahtera dalam membangun citra partai, menentukan strategi dalam memelihara hubungan positif dengan media, serta pemanfaatan media sosial dalam membentuk opini calon gubernur Jawa Barat Tahun 2018. Penelitian menggunakan paradigm konstruktivis, pendekatan kualitatif dan metode studi kasus. Hasil penelitian menunjukan bahwa, Public relation politik di internal Partai Keadilan Sejahtera dilakukan dengan membangun kebersamaan dan konsolidasi sekaligus dengan pembinaan kader secara kekeluargaan dan kesetaraan. Komunikasi internal PKS mulai dibenahi dan dikondisikan, terutama dalam penyebaaran informasi di internal PKS. Komunikasi eksternal PKS dilakukan dengan membangun citra positip partai, membangun koalisi dengan partai lain, dan mensosialisasikan karakteristik calon gubernur Jawa Barat sehingga bisa diterima oleh masyarakat. Strategi pencitraan yang
\end{abstract}


Khoiruddin Muchtar dan Aliyudin

dilakukan oleh Partai Keadilan Sejahtera di media dilakukan dengan cara membangun hubungan yang baik dengan media dan memanfaatkan media social secara tepat seperti halnya pemanfaatan E-mail, blog, media sosial ataupun Twitter. Perolehan suara PKS sebagai runner up Pilgub Jabar 2018 menunjukan, eksistensi PKS sebagai partai yang cukup dipercaya dan diperhitungkan.

Kata Kunci: Strategi, Public Relations, Pemilukada, Partai Keadilan Sejahtera.

\section{PENDAHULUAN}

Sepanjang kurun waktu 1998-2005, PKS merupakan kelompok fundamentalis, yang berkembang di kalangan menengah perkotaan, namun berbeda dari kelompok Islam modernis lainnya seperti Muhammadiyah, Persis, dan sebagainya. Sebagai salah satu partai yang berlaga di dalam pemilu di lndonesia, PKS tetap setia dengan pandangan Islam fundamentalisnya, akan tetapi menunjukkan pandangan moderat dalam berbagai hal. fundamentslisme moderat setuju untuk bersikap kooperatif dan kompromi terhadap pihak lain sejauh kepentingan dan tujuan politik mereka juga terakomodasi. fundamentalis moderat cenderung setuju dengan demokrasi, karena dengan demokrasilah mereka bisa eksis, dan memberikan ruang untuk sebuah pemerintahan yang populer berdasarkan nilai-nilai Islam (Firman, 2007).

Berdasarkan fenomena tersebut, keterlibatan Partai Keadilan Sejahtera dalam sistem demokrasi elektoral di Indonesia menimbulkan pertanyaan, apakah mungkin bagi sebuah partai politik yang memiliki ideologi religius untuk meliberalisasi dan menghibur demokrasi, mungkin karena PKS tidak memiliki pilihan selain melakukan negosiasi dan berinteraksi dengan aktor politik lainnya melalui koalisi dan politik parlementer, bahkan dituntut untuk memperluas pemilihnya hingga menjangkau pemilih non-Islam (Hasan, 2012).

Kesediaan untuk menerima demokrasi, masuk di parlemen dan berkompetisi memperebutkan segmen politik non-Islam, menunjukan bahwa, PKS sama sekali bukanlah ancaman bagi demokrasi. PKS percaya bahwa prinsip demokrasi dapat ditemukan dalam Islam dan konteks Indonesia. Bagi PKS, demokrasi membuka ruang kesempatan bagi partai politik Islam untuk mencapai tujuan politiknya (Nurdin, 2011). PKS sudah lama membuka diri dan melakukan perubahan ke arah yang lebih komunikatif dengan kelompok lain, sehingga muncul beberapa pemimpin daerah yang berasal dari kader PKS.

Partai Keadilan Sejahtera selama ini sering memunculkan kader-kader yang mempunyai kemampuan yang dapat membawa perubahan, di beberapa daerah, partai keadilan sejahtera juga berhasil mengusung orang-orangnya menjadi pemimpin di tingkat daerah (Utomo \& Turtiantoro, 2013). PKS Jawa Barat termasuk yang telah berhasil mengusung dan menempatkan kadernya menjadi Gubernur Jawa Barat selama dua periode berturut-turut, padahal PKS sendiri bukan partai pemenang dalam dalam Pemilu Legislatif di Jawa Barat. 
Jawa Barat merupakan suatu daerah yang memiliki potensi besar untuk mendulang suara pemilih. Jawa Barat memiliki posisi strategis, terutama dari segi wilayah yang memiliki akses terdekat ke pemerintahan pusat. Semua partai politik berupaya menyusun strategi untuk meraih kemenangan dalam Pemilihan Gubernur Jawa Barat dan Pilkada serentak di 16 daerah pada 2018 mendatang. Posisi Gubernur Jawa Barat sangat diperhitungkan oleh semua partai politik, karena diprediksi akan menyokong keberadaan partai pendukung tersebut.

Masyarakat Jawa Barat secara umum merupakan masyarakat yang paling siap berdemokrasi, dibuktikan dengan hasil Pemilu yang selalu berubah dan dinamis. Masyarakat Jawa Barat cenderung memilih parpol yang memiliki program realistis. Di daerah ini tidak pernah ada parpol yang menguasai secara mutlak dulu pernah menjadi pemenang, kemudian PDIP dan berikutnya adalah Demokrat (Bainus, 2017).

Sebagai organisasi politik, partai meninginkan terciptanya citra positip, citra positip dapat ditunjukan melalui penyikapan terhadap peristiwa politik sesuai dengan aspirasi yang sesuai dengan kehendak konstituennya (Muchtar, 2016:146). Semakin besar konstituen maka akan semakin signifikan pendukung partai tersebut untuk memenangkan suatu Pemilihan kepala daerah.

Uniknya, Parpol pemenang Pemilu di Jawa Barat belum tentu bisa memenangkan calon yang diusungnya. Terbukti selama periode ini yang menjadi Gubernur adalah Ahmad Heryawan, bukan dari partai pemenang Pemilu. Partai Keadilan Sejahtera (PKS) hanya menempati urutan keempat raihan suara terbanyak pada Pemilu Legislatif 2014 untuk DPR wilayah di Jawa Barat, Padahal pada tahun 2013 PKS memenangkan Pilgub Jawa Barat dengan mengusung Ahmad Heryawan dan Deddy Mizwar

Suara PKS di Jawa Barat tidak pernah signifikan, keberadaan Ahmad Heryawan sebagai Gubernur Jawa Barat tidak berdampak besar bagi suara PKS. walaupun PKS mendapat dua kali kemenangan pada dua kali Pilgub, itu bukan karena faktor Aher melainkan wakil Gubernurnya, Deddy Mizwar, sedangkan kemenangan sebelumnya karena ada Dede Yusuf (Bainus, 2017). Fenomena tersebut mengisyaratkan, bahwa semua calon yang diusung partai politik memiliki peluang dan kesempatan yang sama tergantung dari kemampuan dalam membangun komunikasi dan jaringan dengan tokoh dan masyarakat Jawa Barat.

Penelitian tentang pemilukada banyak dilakukan sebelumnya, beberapa aspek kajian terfokus pada beberapa hal, diantaranya adalah, terkait dengan kebijakan birokrasi dan dinamika partai sebagai pengusung calon yaitu penelitian tentang, Peran dan Fungsi DPRD dalam Pelaksanaan Pilkada Menurut UndangUndang No. 32 Tahun 2004 (Muis, 2009), Politisasi Birokrasi dalam Pilkada Banten 2006 (Hamid, 2011), Menyoal Peran Panitia Pengawas Pemilu dalam Pilkada (Zainuddin, 2009) dan Metamorfosis Faksionalisme Internal Partai Golkar di Maluku Utara Pada Pilkada 2007 (Misrina, 2010). 
Penelitian Pilkada yang terkait dengan peranan perempuan diantaranya adalah Perempuan dan Pilkada Langsung (Marwah, dkk, 2008), Isu Perempuan Sebagai Strategi Komunikasi Politik Kampanye Calon dalam Pilkada (Handoko, 2009). Sedangkan penelitian pilkada terkait dengan peran tokoh keagamaan adalah tentang Peranan Kepemimpinan Alim Ulama dalam Meningkatkan Partisipasi Pemilih Pada Pilkada di Kota Padang Panjang (Fitri, dkk, 2019) dan Peranan Tokoh Agama dalam Meningkatkan Partisipasi Politik Masyarakat Pada Pilkada Bupati 2010 di Kabupaten Halmahera Selatan (Aya, 2013).

Pilkada dikatakan pula sebagai ajang adu strategi bagaimana bisa mendapatkan suara sebanyak-banyaknya untuk pemenangan calaon kepala daerah, sehingga penelitan pilkada juga banyak yang mengaitkannya dengan strategi yang diterapkan diantaranya adalah penelitian tentang Strategi Kemenangan Pasangan Tatto Suwarto Pamuji-Akhmad Edy Susanto dalam Pilkada Kabupaten Cilacap Tahun 2012 (Insani, M. A. (2013), Analisis dan Eksistensi Politik Kandidat Walikota dalam Meyakinkan Pemilih Pada Pilkada Kota Makassar di Tinjau dari Aspek Marketing Mix (Launtu, 2009) dan Representasi Black Campaign dalam Spanduk Kampanye Pilkada Jakarta 2012 (Anugerah, dkk, 2013).

Dinamika krisis dan konflik juga menjadi bagian yang banyak dikaji dalam penelitian Pilkada, diantaranya adalah, Local Political Dynamics In The General Election Directly Conducted To Vote For District Heads (Pilkada) In Badung Regency In 2005 (Wisnumurti, dkk, 2011), Pilkada Kabupaten Bekasi 2007: Mengakhiri Sebuah Krisis Politik (Susila, 2009) dan Resolusi Konflik Pilkada di Kota Cimahi Jawa Barat (Humaedi, dkk, 2018).

Implementasi dan wawasan terkait Pilkada, banyak juga menjadi sorotan dalam penelitian terdahulu diantarnya adalah, Pemantapan Wawasan Kebangsaan dalam Mengsukseskan Pilkada (Basyah, 2010), Kemenangan Kembali Mantan Bupati Amat Antono Pada Pilkada Kabupaten Pekalongan Tahun 2011 (Maula dkk, 2013), Fenomena Golput Pada Pilkada Pati 2011 (Masitoh dkk, 2013), Implementasi Penerapan Pilkada pada daerah Pemekaran (Siregar, 2012), dan Variabel-variabel yang Mempengaruhi Rendahnnya Partisipasi Politik Masyarakat dalam Pilkada Walikota dan Wakil Walikota Padang Tahun 2008 (Hendrik, 2010)

Meskipun memiliki beberapa kesamaan dengan penelitian terdahulu, namun penelitian ini penekanannya lebih kepada public relations politik, bagaimana PKS sebagai sebuah partai politik memanfaatkan peluang-peluang menjalin komunikasi secara internal dan eksternal, serta bagaimana PKS menjalin hubungan dan memanfaatkan media dalam kampanye, sehingga mampu menjual program dan calon yang diusungnya.

Fenomena keberhasilan PKS dalam memenangkan Pilkada Gubernur Jawa Barat dua kali berturut-turut menjadi hal yang menarik untuk dikaji, terutama dari aspek strategi public relations yang dilakukan Partai Keadilan Sejahtera 
sehingga bisa mendapatkan simpati masyarakat Jawa Barat.

Berdasarkan fenomena tersebut, fokus kajian ini bertujuan untuk mengungkap tentang, strategi public relations politik PKS dalam memenangkan Pemilukada Gubernur Jawa Barat Tahun 2018, sehingga diperoleh gambaran tentang managemen image dan media, komunikasi Internal dan eksternal, serta memperoleh gambaran mengenai managemen informasi Partai Keadilan Sejahtera.

Penelitian diharapkan memiliki manfaat dan memberikan kontribusi pemikiran bagi pengembangan ilmu sosial, khususnya ilmu komunikasi, utamanya adalah komunikasi politik terkait dengan proses pemenangan Partai keadilan sejahtera dalam Pemilukada Calon Gubernur Jawa Barat Tahun 2018 dengan memperhatikan strategi public relations politik yang dilakukan para kader partai keadilan sejahtera. Penelitian ini diharapkan pula dapat menjelaskan model public relations politik yang dilakukan kaderpartai keadilan sejahtera.

Penelitian ini juga diharapkan dapat memberikan kontribusi pemikiran tentang strategi komunikasi politik dalam pemenangan Pemilukada calon Gubernur dan bagaimana strategi public relations politik yang mesti dilakukan agar partai politik dapat memperoleh kemenangan secara efektif atas calon yang diusungnya. Penelitian diharapkan mampu memberikan pedoman dan pandangan bagi para aktivis dan praktisi politik dalam melakukan komunikasi dengan baik dan tepat dalam berbagai momen kegiatan politik, memiliki kemampuan dalam melakukan manajemen media, image, maupun manajemen informasi.

\section{HASIL DAN PEMBAHASAN}

\section{Membangun Kebersamaan dan Soliditas Internal Partai}

Partai Keadilan Sejahtera sebagai partai yang dianggap selalu konsisten dengan keislamannya dan menyatakan diri sebagai partai dakwah, mereka selalu berusaha untuk membangun soliditas di lingkungan internalnya. PKS menginginkan terciptanya kekuatan dan soliditas partai yang harus dimulai dari lingkungan internal terlbih dahulu. Karena mereka beranggapan bahwa, untuk bisa banyak berkontribusi bagi bangsa dan Negara harus dimulai dari dalam partai dahulu, baru kemudian bisa berkiprah lebih luas.

Sebelum menelaah lebih jauh, konsolidasi yang dijalani PKS agak unik, karena mengandung empat aspek. Pertama, konsolidasi ideologi yang tertuang dalam Falsafah Dasar Perjuangan (2007), sebenarnya merupakan elaborasi dari Manifesto Politik PK yang dirumuskan tahun 1998, yakni kristalisasi pemikiran yang mendasari berdirinya partai berdasarkan nilai-nilai spiritual dan pengalaman sejarah panjang. Piagam Deklarasi PK (1998) dan PKS (2003) serta seluruh materi kaderisasi PKS dapat dicerna dengan jernih, apabila memakai kerangka falsafah dasar perjuangan ini. 
Khoiruddin Muchtar dan Aliyudin

Kedua, konsolidasi politik termaktub dalam Platform Kebijakan Pembangunan PKS yang memuat langkah-langkah strategis PKS untuk memperbaiki kondisi bangsa. Platform PKS tahun 2003 berjudul "Agenda Penyelamatan Bangsa", tahun 2007 dipertegas menjadi "Memperjuangkan Masyarakat Madani", dan tahun 2017 direvisi menjadi "Indonesia Madani". Di sinilah seluruh upaya politik PKS dikomunikasikan kepada publik Indonesia dan dunia, tidak ada yang disembunyikan (hidden agenda). Seluruh anggota DPR RI dan DPRD dari Fraksi PKS di seluruh Tanah Air harus memahami dan menjalankan platform kebijakan, karena mereka sebagai etalase dan juru bicara PKS di arena publik.

Ketiga, konsolidasi organisasi termuat dalam Anggaran Dasar dan Anggaran Rumah Tangga PKS, yang mengatur tertib organisasi sejak di tingkat pusat, wilayah, daerah, cabang dan ranting. Ada yang unik dalam tradisi (konvensi) PKS, yakni arahan pimpinan (khithob qiyadi) berfungsi penting karena menjadi pengarah dalam praktek kehidupan berorganisasi. Lembaga pengambil keputusan tertinggi dalam PKS adalah Majelis Syura (yang anggotanya dipilih secara berkala dan demokratis lewat pemilihan raya), dan posisi Ketua Majelis Syura sebagai mandataris MS sangat sentral. Siapapun kader PKS yang pernah berhadapan dengan Ketua MS PKS berarti dia berhadapan dengan pemegang mandat tertinggi, seperti kader PDIP berhadapan dengan Megawati atau kader PD berhadapan dengan SBY.

Aspek keempat adalah konsolidasi basis massa yang belum tuntas dirumuskan PKS, karena sepanjang dua dekade pasca reformasi belum terbentuk basis sosial baru dalam perpolitikan Indonesia. PKS masih dicirikan sebagai partai urban dengan konstituen mayoritas kaum terdidik, padahal hasil pemilu 2014 menunjukkan perluasan suara PKS hingga ke daerah pedalaman (Papua/Papua Barat), dan turun/stagnannya dukungan PKS di daerah perkotaan. Target pemilu bagi PKS selaku 'Partai Dakwah' bukan semata perolehan suara meningkat, melainkan apakah basis sosial baru tumbuh untuk melakukan transformasi bangsa? Menyadari posisinya sebagai partai menengah, PKS terbuka untuk berkolaborasi dengan kekuatan sosial-politik manapun yang sejalan dengan visi-misi Indonesia Madani.

Di tengah dinamika organisasi dan gejolak politik nasional/global saat ini, penting sekali bagi PKS untuk melakukan konsolidasi pemikiran dan hati. Kader PKS sudah terlatih menghadapi berbagai tantangan. PKS merupakan partai yang serius melaksanakan misi perbaikan organisasi dan kondisi bangsa, sehingga PKS pasti akan menghadapi tantangan berat dari berbagai penjuru (Waluyo, 2018)

Karena itu dengan kualitas kader yang mumpuni, PKS menargetkan kadernya meraih suara 19\% pada Pemilu 2019. Dengan kader seperti itu, wajar kalau nanti di tahun 2019, PKS ingin menjadi partai papan tengah. PKS berharap akan meraih suara di atas 10 persen (Putra, 1999). 
PKS berupaya agar para kadernya selalu membangun negeri secara bersama-sama dengan tidak memandang perbedaan suku, agama, ataupun golongan. Bangsa Indonesia adalah plural, segmented, dan fragmented, sehingga perlu membangun kebersamaan dengan seluruh elemen masyarakat. Melahirkan kepedulian dan kebersamaan. Dalam konteks nasional, PKS ingin jadi pelopor perwujudan cita-cita nasional.

Kader PKS berharap kadernya bisa menjadi kontributor peradaban dunia. PKS ingin Indonesia semakin aktif dalam kerja sama dengan lembaga lain, ataupun parpol di negara lain. PKS ingin jadi kontributor peradaban dunia yang semakin adil, damai dan sentosa.

Untuk membangun kebersamaan PKS juga mengadakan peringatan Hari Besar Islam dengan mengumpulkan beberapa pengurus, kader dan konstituen PKS. Peringatan Maulid Nabi menjadi sebuah momen tersendiri untuk membangun soliditas dan kebersamaan partai, karena tradisi maulid yang selama ini dilakukan masyarakat Indonesia cukup ampuh menjaga akidah dan semangat kaum muslimin untuk menjaga keberlangsungan kehidupan beragama, bermasyarakat dan bernegara di Indonesia.

Konsolidasi internal partai terus dilakukan terutama menjelang Pilgub Jawa Barat Tahun 2018. Konsolidasi dilakukan sekitar di wilayah Jawa Barat, acara konsolidasi lebih sering dilakukan oleh calon Gubernur dari PKS yaitu Ahmad Syaikhu beserta Tim.

Modal terkuat untuk memenangkan pilkada, adalah dengan menggerakan mesin partai. Kedatangannya ke berbagao derah di Jawa Barat bertujuan untuk mengingatkan pada semua jajaran agar menjaga soliditas dan menjamin tidak adanya friksi di dalam partai. Kader di setiap daerah siap untuk bergerak. Hal ini merupakan kunci dari kemenangan pilgub Jabar 2018.

Roadshow PKS dilakukan mulai September hingga awal Nopember 2017. Inti roadshownya, bertemu seluruh jajaran struktur maupun kader serta simpatisan di Jabar. Targetnya tidak ada lagi keraguan untuk memberikan dukungan untuk pemenangan pasangan Calon Gubernur yang diusung PKS.

Komunikasi dan organisasi terdiri dari dua konsep, namun bisa dibilang keduanya sudah saling terkait satu sama lain dan tidak bisa untuk dipisahkan. Komunikasi memegang peranan penting dalam suatu organisasi ataupun partai politik, sebagai sarana untuk saling berbagi informasi antara para anggota atau pihak yang berada dalam organisasi atau partai politik.

Informasi digunakan untuk menyamakan pandangan para anggota, menentukan tujuan, hingga memutuskan suatu pilihan yang harus diambil oleh organisasi tersebut. Selain dengan cara berkomunikasi pada umumnya, dalam organisasi, terdapat cara khusus untuk berkomunikasi seperti menggunakan memo atau catatan kecil, surat-menyurat, peraturan dan kebijakan yang ditentukan, hingga jumpa pers dengan publik. 
Partai Keadilan Sejahtera memberlakukan sistem kaderisasi dengan berbagai jenjang, Jenjang tersebut berfungsi sebagai sarana untuk membangun komunikasi dan memilah orang-orang yang disiapkan untuk ditempatkan pada posisi-posisi tertentu, seperti halnya untuk dicalonkan sebagai anggota legislatif, bupati, gubernur, presiden dan lain sebagainya.

Kader PKS adalah kader terbina, yaitu yang secara intens berkomunikasi dan berinteraksi dengan partai sangat erat. Seorang kader sekurang-kurangnya adalah minimal harus mengikuti pembinaan "pekanan", yaitu pembinaan rutin setiap satu minggu sekali dengan sistem group atau kelompok, momen inilah yang kemudian dimanfaatkan sebagai ajang komunikasi internal yang dilaksanakan melalui grup-grup binaan. Kebijakan, arahan, maupun informasi atau lainnya disampaikan melalui group binaan. Kader dibina dan saling membina antar jenjang pembinaan, dan kontinuitas sistem ini terus dijaga guna mempertahankan soliditas antar anggota partai.

Partai Keadilan Sejahtera merupakan partai dakwah, dan mengklaim dirinya sebagai partai bercorak Islam, sehingga kampanye dan sosialisasinya mengarah ke gerakan dakwah. PKS selala fokus pada pengkaderan atau pembinaan kader dan dalam kegiatan pembinaan kader itulah identitas partai, kebersamaan dan kesatuan, integritas, serta loyalitas anggota partai PKS terbentuk.

Tradisi yang diberlakukan di PKS, Jika tiga kali tidak hadir dalam pembinaan "pekanan" dengan alasan yang tidak dapat diterima, maka akan ada sanksi atau hukuman sesuai dengan pedoman untuk anggota partai yang sudah ada dan disetujui oleh semua anggota. Karena keterikatan seorang kader dengan partai ini minimal menghadiri pembinaan pekanan.

Dalam kegiatan pekanan itulah PKS mencoba untuk menempa, membentuk karakter, sehingga tercipta kader-kader yang berkarakter baik di tengah masyarakat dan ketika menjabat ia akan menjadi pejabat yang baik, akidahnya benar, akhlaknya juga baik, ibadahnya benar, kemudian bermanfaat di tengah-tengah masyarakat, dan sesuai dengan 10 karakter yang sudah ditetapkan dalam pembinaan tersebut.

Terdapat enam jenjang keanggotaan dalam keanggotaan PKS, yakni; anggota pemula, muda, madya, dewasa, ahli, dan anggota purna. Dengan kurikulum pembinaan dalam setiap jenjangnya. Penjenjangan ini merupakan upaya untuk membentuk kader, sesuai dengan kecenderungan dan talenta dalam berbagai bidang seperti kecenderungan ke dunia politik, pendidikan, sosial, dan lain sebagainya, ia akan di distribusikan ke dalam bidang tersebut berdasarkan bakat dan kemampuannya.

Adapun "Pekanan" merupakan aktivitas internal partai sebagai agenda pembinaan rutin setiap sepekan sekali yang wajib diikuti oleh semua anggota partai pada setiap jenjang keanggotaan. Feedback dari anggota partai terhadap 
Public Relations Politik Partai Keadilan Sejahtera dalam Pemilukada Jawa Barat

aktivitas pekanan ini dinilai baik, karena mereka wajib mengikutinya secara rutin sehingga kontinuitas tersebut menjadikan pemahaman para anggotanya sinkron satu sama lain.

\section{Membangun Citra Positif Partai}

Citra politik di masyarakat akan positif jika partai politik dan politikus memegang nilai-nilai kebangsaan, baik dalam tindakan politik maupun dalam perilaku sehari-hari di masyarakat. Sosialisasi kebijakan partai hendaknya dilakukan dengan menunjukkan kesalehan struktural dan kesalehan kultural, yakni kesalehan yang ditunjukkan dalam kegiatan organisasi partai dan kesalehan yang ditunjukkan dalam perilaku kader secara individu dalam komunitas masyarakatnya, untuk menumbuhkan kepercayaan dan simpati masyarakat (Muchtar, 2013: 116)

Bagi Partai politik akan dicitrakan negatif oleh masyarakat bila tidak memikirkan persoalan bangsa apalagi mencari keuntungan atau kekayaan bagi para anggotanya. (Pobottinggi, 2013). Kondisi ini membuat publik tidak terlalu antusias dengan kemunculan parpol baru. Setidaknya, tiga dari empat responden menilai, kehadiran parpol baru saat ini tak diperlukan. Parpol baru bukan jawaban atas kebutuhan akan sarana agregasi politik publik. Pendapat publik itu antara lain dibangun oleh pemahaman umum terhadap parpol pada saat ini. Citra sifat feodalistik atau sentralistik masih melekat pada parpol.Semua keputusan organisasi dilakukan pimpinan pusat, termasuk pemilihan wakil rakyat dan kepala daerah.

Sebanyak 76 persen responden jajak pendapat ini berpendapat, parpol hanya memperjuangkan kepentingan kelompok. Parpol dipandang sebagai tempat bercokolnya para pemburu popularitas, pencari kehormatan secara sosial, dan pengejar harta secara ekonomi.Tak bisa dipersalahkan jika publik memiliki pemahaman seperti itu.Pasalnya, kisah politisi yang berhasil masuk ke legislatif cenderung bertarung untuk kuasa dan uang dan yang tak beruntung akhirnya terjerat hukum kini kerap menjadi konsumsi publik.

Imaji parpol di Indonesia saat ini masih identik dengan tokoh senior partai. PDI Perjuangan identik dengan Megawati Soekarnoputri.Partai Demokrat identik dengan Susilo Bambang Yudhoyono, Partai Hanura dengan Wiranto, dan Partai Gerakan Indonesia Raya dengan Prabowo Subianto.Bahkan, Partai Nasdem yang relatif baru sudah identik dengan Surya Paloh.Dalam kondisi ini, meski cenderung bersikap apatis, publik menaruh harapan terhadap parpol baru yang banyak menyasar kader muda dan dinamis.

Parpol baru diharapkan dapat menawarkan alternatif sosok pemimpin nasional baru.Publik juga berharap, parpol baru tampil sebagai parpol yang modern dan bersih dengan ideologi baru dan pro rakyat. Kerinduan akan hadirnya parpol yang modern menunjukkan bahwa ada keinginan untuk keluar 
Khoiruddin Muchtar dan Aliyudin

dari bentuk parpol lama. Secara tidak langsung ini menampakkan, parpol yang ada belum berhasil menanamkan nilai dan cita-cita kepada konstituennya.Ideologi partai sekadar seremonial yang dicantumkan dalam visi dan misi.

Mayoritas publik menyoroti berbagai fungsi parpol, mulai dari penyalur aspirasi, tempat melakukan pendidikan politik, perekrutan politik, penggalangan partisipasi publik, hingga kontrol terhadap pemerintah, tidak berjalan sebagaimana mestinya. Secara umum, setidaknya 6 dari 10 responden tidak puas terhadap kinerja parpol selama ini.

Sikap parpol yang lebih mementingkan kelompok turut memperburuk citra parpol di mata publikpun dalam mempersiapkan kadernya untuk diusung dalam pemilihan kepala daerah, mayoritas publik menilai parpol belum berhasil dalam hal tersebut. Namun, kinerja yang dipandang masih buruk tidak sertamerta membuat citra positif parpol turun drastis.Bahkan, citra parpol cenderung naik dalam beberapa tahun terakhir.

Di balik berbagai kasus korupsi anggotanya, beberapa parpol dipandang masih konsisten memperjuangkan kepentingan rakyat. Sudah saatnya parpol tak lagi abai dan menempatkan rakyat sebagai prioritas dalam implementasi kiprahnya. Rakyat tak sekadar diusung sebagai jargon menjelang pemilu lantas ditinggalkan ketika perhelatan demokrasi usai.Kini, yang dibutuhkan adalah bukti nyata keberpihakan parpol dalam menyejahterakan rakyat Indonesia (Handining, 2016).

PKS sebagai partai yang lahir pasca reformasi ini berupaya menjaga citranya dengan melakukan perubahan-perubahan orientasi yang lebih terbuka dan kerakyatan, tidak lagi menjadi partai ekslusif, tidak lagi memiliki icon sebagai partai kelas menengah. Bukti nyata hasil kerja akan menjadi poin tersendiri untuk mendapatkan citra positif dari masyarakat, namun apabila PKS tetap saja tidak merubah mainset politik tersebut, maka PKS tidak akan mendapatkan kepercayaan masyarakat secara luas sampai ke tingkat akar rumput.

Fenomena PKS di atas mengantarkannya sebagai partai modern yang diperhitungkan. Beberapa faktor dapat dikaji terkait kondisi PKS dari awal hingga kini. Pertama terkait vitalitas sistemnya. Capaian PKS di Pemilu 2014 lalu jauh dari prediksi sejumlah lembaga survei. PKS diprediksikan jeblok dan tidak lolos parliementery threshold pasca kasus yang menimpa LHI.

Signifikansi suara yang menjungkirbalikkan prediksi disebabkan oleh faktor kuatnya vitalitas PKS. PKS berhasil mempertahankan suara di tengah badai lantaran faktor kaderisasi yang baik, soliditas kader, dan kinerja di lapangan.

Kedua terkait virtualitas politiknya. Hasil survei Awesometric di berbagai media menunjukkan bahwa Partai Keadilan Sejahtera (PKS) adalah partai politik yang paling disebutkan (the most mentioned). PKS dilaporkan lebih dari 213 
ribu kali pada arus utama dan media sosial selama periode sebelum Pemilu 2014. Posisi kedua adalah Partai Demokrat dengan 203.247 kali, disusul oleh Partai Golkar, Gerindra, dan PDIP.

Ketiga terkait kecerdasan dan konsistensi perjuangannya. Kampanye PKS selama pemilu dipandang publik cukup atraktif dan kreatif, baik di media maupun lapangan. Isu yang diangkat juga beragam. Hal ini menunjukkan kecerdasan pengemasan politik oleh PKS. Capaian ini didukung oleh kader PKS yang sebagian besar berpendidikan tinggi.

Perbaikan Nasib

Capaian di atas bukannya tanpa kekurangan dan tantangan. PKS masih mendapatkan stigma negatif dari sebagian kalangan. Kalangan liberal menganggap PKS terlalu Islamis. Kalangan Islamis menganggap PKS mulai liberal. PKS mesti memperbaiki nasib ke depan dengan strategi jitu.

Dilema ini penting segera diselesaikan dan dikomunikasikan terhadap berbagai kalangan. Kasus-kasus kecil juga selalu diangkat misalnya cap PKS Wahabi, anti tahlilan, dan lain-lain. Beberapa kalangan kecil masih mencurigai agenda Islamisasi PKS dan menyangsikan genealogi ke-Indonesia-an PKS. Hal inilah tantangan PKS ke depan yang mesti dijawab tuntas. PKS mesti mampu membumikan ideologi, gagasan, dan ide-idenya dalam konteks ke-Indonesiaan.

PKS juga dituntut semakin memacu diri dalam modernisasi demokrasi. Hal ini dapat dilakukan melalui intelektualisasi politisinya dan pendidikan politik publik. Modal PKS adalah memiliki kader dengan kadar intelektual tinggi. Sejatinya politik adalah industri pemikiran yang bertugas memberi arah bagi kehidupan masyarakat (Matta, 2013).

PKS mesti tampil terdepan dengan teladan politisinya yang selalu memproduksi gagasan intelektual agar menghasilkan pemikiran jitu menyelesaikan persoalan bangsa. Alfian (2013) menyarankan agar politisi membuka diri dan bekerja sama lebih erat dengan para intelektual agar terbentuk pola intelektualisasi politik yang mandiri dan kreatif.

Dinamika politik terkini menguji efektifitas strategi PKS. Konsisten menjadi oposan memberikan konsekuensi pada minimnya sumber daya yang direngkuh. Namun belajar dari PDIP dan Gerindra yang menjadi oposan selama 10 tahun, justru berbuah manis sebagai jawara pemilu 2014.

Keunggulan PKS yang tidak mengandalkan figur dan mengoptimalkan peran kader akan berpotensi mengantarkannya menjadi partai besar. Hal ini akan terjadi ketika kelak partai-partai lain kehilangan tokoh, gagal melakukan regenerasi, dan berkutat pada pusaran konflik. Kuncinya PKS mesti menghindari godaan korupsi, konflik internal, dan membumi dengan kemajemukan bangsa (Lupiyanto, 2016)

Sebagai upaya mempertahankan pencitraan partai, PKS berkomitmen mengaktualisasikan prinsip dasar partainya sebagai partai dakwah dan kader 
dalam konteks tantangan Indonesia yang semakin kompleks.

Tantangan PKS adalah bagaimana prinsip dasar partai bisa teraktualisasi, sehingga dibutuhkan kerja keras dari internal PKS untuk mengaktualisasikan prinsip dasar tersebut, dalam konteks tantangan Indonesia. PKS sebagai partai dakwah tidak bisa bekerja sendiri dan akan menjalin kerja sama dengan semua pihak. Baik di tingkat regional maupun internasional.

Sebagai partai dakwah yang berbasis kader, PKS sejak awal terus melakukan upaya agar prinsip partai dakwah dapat diaktualisasi. Ini merupakan tantangan terbesar bagi kepemimpinan yang baru ini, yaitu bagaimana PKS dapat mengaktualisasi partai dakwah ini dalam konsep Islami. PKS harus dapat berimprovisasi dan berinovasi agar nilai-nilai Islam dapat diterima oleh masyarakat Indonesia, terlebih dalam kondisi masyarakat Indonesia saat ini.

PKS tidak dapat bekerja sendirian. PKS harus menjalin kerjasama dengan seluruh pihak, baik dengan pemerintah, parpol lain, maupun elemen lain di dalam negeri atau di luar negeri. PKS memiliki cita-cita menjadi partai dakwah yang akan melayani bangsa. Seperti yang ada dalam AD/ART PKS, yaitu bersih, peduli, dan profesional.

Saat ini mereka berusaha mengubah mindset publik bahwa kepengurusan yang baru ini lebih Islami ketimbang yang sebelumnya. karena kepengurusan saat ini pemimpinnya dari kubu yang berbeda. Pengurus PKS saat ini didominasi oleh faksi keadilan ketimbang faksi sejahtera. Faksi keadilan dalam PKS adalah orangorang yang masih menganut paham lama. Orientasi faksi keadilan ini adalah mendirikan partai yang orientasinya pada dakwah Islam. Sedangkan faksi sejahtera adalah orang-orang yang berorientasi politis pragmatis.

PKS sedang melakukan politik pencitraan dengan mengubah struktur pimpinan yang berasal dari faksi keadilan. Mengembalikan orientasi menjadi partai dakwah yang terlepas dari politik pragmatis. Selagi berada di luar pemerintahan, PKS saat ini sedang mengembalikan arah dakwahnya, setelah sejumlah kadernya terjerat kasus korupsi akibat terlalu bermain dengan poltik pragmatis, saat ini, PKS berusaha mengubah citra menjadi partai dakwah, seperti konsep Partai Keadilan pada awal berdirinya.

Sebelumnya, beberapa kader PKS terjerat korupsi. Mantan Presiden PKS Luthfi Hasan Ishaaq terjerat kasus korupsi suap impor daging. Yang terbaru, Gubernur Sumatera Utara Gatot Pujo Nugroho, tersangka kasus dugaan suap terhadap hakim PTUN Medan (Heryanto, 2015).

Penanganan kasus korupsi yang melibatkan para kader PKS tersebut menjadi beban tersendiri bagi upaya pencitraan partai. PKS hendaknya mengakhiri perseteruan dengan KPK, dan tidak lagi menghalang-halangi KPK untuk melakukan pemeriksaan dan penyitaan mobil, bila hal ini tidak dihentikan, maka dikhawatirkan akan berimplikasi negatif pada citra PKS dalam proses Pilgub dan Pemilu caleg. 
Semakin pelik perseterun, maka akan semakin menarik perhatian publik. Sehingga pada gilirannya, tidak menutup kemungkinan akan terbangun persepsi dibenak public, bahwa PKS adalah partai yang dekat dengan persoalan korupsi., Karena sejauh ini publik mempunyai kepercayaan yang lebih tinggi kepada KPK dari pada kepada partai politik. Sehingga pemilih akan mulai berpikir dua kali untuk memilih PKS dan para calegnya saat pemilihan nanti.

Meskipun PKS ini sudah menguasai Jawa Barat dalam 10 tahun terakhir dengan mengusung Ahmad Heryawan menjadi Gubernur Jabar selama dua periode, namun belum menjadi jaminan akan terulang lagi bagi pasangan AjatSyaikhu. PKS pun tetap dituntut untuk bekerja keras agar bisa kembali memenangkan gelaran pemilihan gubernur. Semua kader PKS bergerak secara sistematis meningkatkan popularitas dan elektabilitas Sudrajat-Syaikhu.

Salah satu strategi PKS untuk memenangkan Pilgub Jabar 2018 yaitu dengan mengoptimakan komunikasi dengan daerah asal Sudrajat dan Syaikhu. Sudrajat didorong untuk lebih inten bersosialisasi di wilayah Priangan, sementara Syaikhu akan dioptimalkan di wilayah pantura. Sudrajat menilai kesuksesan Ahmad Heryawan. Dengan kekuatan tersebut optimis Sudrajat-Syaikhu mampu memenangi Pilgub Jabar

Sebagai partai politik yang mengusung calon gubernur di Pilgub Jawa Barat tahun 2018, PKS menggunakan berbagai strategi pencitraan untuk mendapatkan kemenangan. salah satunya adalah dengan mengerahkan seluruh anggota legislatifnya. Saat ini PKS memiliki 120 anggota legislatif di 27 di kabupaten/kota dan 12 anggota legislatif di tingkat provinsi dan dengan kekuatan entitas politik tersebut maka PKS akan berupaya meneruskan kepemimpinan di Jawa Barat.

PKS juga mengadakan Workshop di tingkat kabupaten/kota dan provinsi ini adalah sebagai upaya mengintegrasikan Pilgub Jabar dan Pilkada Serentak di 16 kabupaten/kota di Jabar. Workshop fraksi ini sebagai aksi cepat tanggap dalam merespons hasil Rakorwil DPW PKS Jabar. Fraksi PKS DPRD Jabar telah membentuk desk pilkada untuk melaksanakan tugas khusus yang diamanatkan dalam Rakorwil.

Selain menggenjot peran anggota legislatif, dalam workshop tersebut, PKS juga akan mengundang sejumlah tokoh dari luar partai untuk memberikan pandangannya terkait dinamika dan situasi politik saat ini. PKS akan menggunakan kaca mata orang lain dulu, setelah itu baru memakai kacamata sendiri agar punya gambaran yang utuh.

Partai Keadilan Sejahtera telah menyiapkan sederet strategi pemenangan untuk menyisihkan beberapa nama yang kerap disebut sebagai lawan berat. Salah satunya, memperhitungkan pergerakan Ridwan Kamil. PKS menerapkan beberapa strategi politiknya untuk mendapatkan kemenangan Pilgub Jaawa Barat diantaranya adalah: Pertama, membentuk tim pemenangan wilayah, bertujuan untuk mencari tahu seberapa besar tingkat popularitas dan elektabilitasnya di 
masyarakat.

PKS juga telah menggalang kekuatan di ranah media social, namun hal yang terpenting adalah dengan terjun langsung ke lapangan, yakni dengan berkomunikasi secara langsung dengan masyarakat. medsos tidak bisa diandalkan begitu saja. Perlu ada hal-hal yang bisa langsung dilihat masyarakat. PKS juga membidik pemilih milenial, yang menurutnya, harus dibimbing dan diedukasi. Ada lebih dari 2.000 kader yang hadir saat ini dan siap mendukung pasangan yang telah dititipkan pimpinan pusat.

PKS dalam pemilu lebih mengandalkan pendekatan persuasive, Setiap anggota PKS di tiap wilayahnya membagikan brosur-brosur ke masyarakat setempat atau langsung ngobrol secara personal. Dan itu menurut PKS dipandang efektif. (wawancara dengan M Alimul Hakim)

Selain itu PKS juga menggunakan strategi untuk menaikkan elektabilitas Sudrajat-Syaikhu dengan melancarkan "serangan udara'. Ada tiga strategi, yang pertama konsolidasi kader. Jadi kader ronda, kader jaga TPS, dan ajak masyarakat berhasil, ini serangan darat. Serangan udara kita menang di media sosial. Media sosial di H-7 digempur habis. H-7 kita merajai media sosial. Lalu endorser kepada 'Asyik' luar biasa. Memang kami berharap apa pun, siapa pun yang menang selamat. Tapi kami melihat fakta realitas, makin menemukan strategi yang tepat untuk ganti presiden di 2019.

Iklan dan promosi program-program dan agenda kegiatan partai PKS, untuk sekarang lebih mengandalkan media social sosial. Seperti: facebook, twitter dan akun sosial media lainnya. Jadi setiap kader minimal harus mempunyai satu akun facebook untuk menyebarkan informasi-informasi terkait program PKS. Selain untuk media promosi dan iklan, bisa juga untuk dijadikan sebagai pencitraan partai PKS (Wawancara dengan M Alimul Hakim).

\section{Citra Partai Keadilan Sejahtera di Media}

Sebagai salah satu partai Islam yang sedang berkembang pesat, Partai Keadilan Sejahtera memiliki citra yang relatif stabil. Hal ini diindikasikan dari eksistensi partai tersebut setelah mengalami beberapa goncangan namun mereka mampu menjaga citra organisasi dengan baik. Media-media mainstream menampilkan partai berlambang Bintang Padi ini dari berbagai sudut; melalui figur dan tokohnya, program-programnya hingga pandangan serta kebijakan politik makro dan mikro.

Pasang-surut citra di media bagi sebuah organisasi, telebih organisasi politik adalah sesuatu yang lumrah. Namun yang lebih penting adalah bagaimana organisasi tersebut mempertahankan eksistensinya dan hal ini berkaitan erat dengan strategi komunikasi politik mereka dalam membangun hubungan baik dengan media sehingga tetap mendapat pandangan yang positif dalam opini publik. Bagaimanapun, citra sebuah organisasi banyak memiliki kaitan erat 
dengan reputasi dan prestasi yang hendak dicapai oleh organisasi tersebut. Pada umumnya landasan citra berakar dari nilai-nilai kepercayaan yang diberikan secara individual dan merupakan pandangan atau persepsi dari publik.

Membangun citra menjadi sebuah keharusan bagi sebuah organisasi atau perusahaan sebab sebagaimana ditekankan oleh Canton yang dikutip oleh (Soemirat \& Ardianto, 2005: 111). bahwa citra merupakan kesan, perasaan, gambaran diri publik terhadap perusahaan (atau organisasi); kesan yang sengaja diciptakan dari suatu obyek, orang atau organisasi. Dengan begitu, citra dapat dikatakan sebagai persepsi masyarakat dari pengalaman yang diperoleh, kepercayaan yang dimiliki, perasaan yang dialami, dan pengetahuan masyarakat itu sendiri terhadap perusahaan, sehingga aspek fasilitas yang dimiliki perusahaan, dan layanan yang disampaikan kepada konsumen dapat memengaruhi persepsi publik terhadap citra.

Secara teoretik, citra perusahaan adalah persepsi yang berkembang dalam benak publik (mengenai realitas yang terlihat) dari sebuah perusahaan atau organisasi. Oleh sebab itu, citra pada dasarnya bersifat dinamis dan tidak lahir begitu saja, melainkan dapat merupakan respon atau feedback dari publik atas eksistensi sebuah organisasi atau perusahaan. Satu hal yang perlu dipahami sehubungan dengan terbentuknya citra perusahaan adalah adanya persepsi. Persepsi didefinisikan sebagai suatu proses di mana seseorang menyeleksi, mengorganisasi, dan menginterpretasi stimulus ke dalam suatu gambaran dunia yang menyeluruh. Stimuli adalah setiap input yang dapat ditangkap oleh indra. Secara sederhana, persepsi adalah pandangan seseorang dalam menafsirkan suatu peristiwa berdasarkan informasi yang diterimanya.

Di sisi lain, kehadiran media sebagai instrument yang memenuhi kebutuhan informasi publik menjadi faktor yang sangat kuat dalam mengarahkan persepsi publik tersebut sehingga secara sederhana dapat dikatakan bahwa informasi yang diterima publik melalui media tertentu akan berhubungan erat dengan citra sebuah organisasi atau perusahaan yang menjadi materi informasi tersebut.

Dengan demikian, pemberitaan tentang suatu perusahaan atau organisasi pada dasarnya merupakan bagian dari pembentukan citra organisasi atau perusahaan tersebut. Sebagaimana diketahui bahwa pemberitaan di media terkait dengan skandal perpecahan Partai keadilan sejahtera dan kasus korupsi yang menjerat kader-kader PKS.

Kondisi ini memaksa Partai keadilan sejahtera untuk kembali membangun strategi komunikasi politik melalui pembentukan kembali citra mereka agar kembali mendapatkan kepercayaan publik. Buruknya citra banyak disebabkan oleh identitas yang juga tidak bergitu baik. Identitas perusahaan adalah apa yang senyatanya ada pada atau yang ditampilkan oleh perusahaan sehingga secara mendasar identitas menampilkan jati diri perusahaan, sementara citra adalah 
persepsi masyarakat terhadap jati diri tersebut (Selamet dalam Sutojo, 2004: 13).

Identitas bukanlah citra tetapi dapat membantu perusahaan atau organisasi mengingatkan masyarakat tentang citra mereka. Namun demikian, identitas merupakan salah satu faktor penting yang memengaruhi keberhasilan pembentukan citra perusahaan di masyarakat. Identitas perusahaan yang baik dan kuat merupakan prasyarat membangun citra baik perusahaan di kelak kemudian hari. Hal itu disebabkan karena seperti halnya dalam kehidupan orang perorangan, identitas perusahaan membentuk kesan pertama. Padahal kesan pertama dapat memengaruhi persepsi orang perorangan atau organisasi selanjutnya. (Sutojo, 2004: 14).

Semakin lama publik mengenal baik sebuah perusahaan atau organisasi (antara lain melalui identitas perusahaan) semakin besar kemungkinan mereka bersikap positif terhadap perusahaan atau organisasi itu. Oleh karena itu, identitas yang baik dan kuat menajdi prasyarat untuk membangun citra yang baik di masyarakat, tidak sedikit perusahaan berusaha keras untuk menciptakan atau memperbaharui identitas mereka secara profesional.

Oleh sebab itu, proses membangun citra positif merupakan bagian yang paling penting dari Public Relations Politik dalam kasus Partai keadilan sejahtera. Dalam menghadapi krisis yang dialami oleh Partai keadilan sejahtera, fungsi PR menjadi sangat vital untuk memulihkan citra sebab sebagaimana dipaparkan oleh (Nova, 2011: 49) bahwa fungsi utama PR adalah menumbuhkan dan mengembangkan hubungan baik antar lembaga dengan publiknya, internal maupun eksternal dalam rangka menanamkan pengertian, menumbuhkan motivasi dan partisipasi publik dalam upaya menciptakan iklim pendapat (opini publik) yang menguntungkan lembaga organisasi.

\section{Strategi Partai Keadilan Sejahtera Memelihara Hubungan dengan Media}

Dalam era media seperti sekarang ini, image war (perang citra) menjadi sesuatu yang lumrah. Semua organisasi berlomba-lomba mencitrakan diri mereka sebagai sesuatu yang positif di mata publik. Pencitraan dengan demikian menjadi aset tersendiri bagi sebuah lembaga, perusahaan dan organisasi untuk membangun citra positifnya agar mendapat dukungan dan simpati dari publik.

Kesadaran akan kuatnya posisi dan peran media dalam proses membangun citra positif juga berdampak pada strategi pencitraan yang dilakukan oleh PKS di media dengan cara membangun hubungan yang baik dengan media. Secara praktis dalam kasus Partai keadilan sejahtera, membangun citra positif dilakukan dalam beberapa langkah sebagai berikut:

Pertama, Partai keadilan sejahtera memilih segmen dengan cara memilih kelompok-kelompok masyarakat yang memiliki peranan penting bagi tumbuh dan berkembanganya eksistensi mereka di masa yang akan datang. Kelompokkelompok masyarakat itu disebut kelompok sasaran atau konstituen. Secara terus 
menerus, Partai keadilan sejahtera wajib mengusahakan agar seluruh konstituen mereka mempunyai persepsi yang positif terhadap jati diri, identitas dan reputasi Partai keadilan sejahtera.

Upaya ini diyakini dapat berdampak pada penyusunan program pembangunan citra partai secara lebih terarah. Dengan menentukan segmensegmen masyarakat yang dijadikan sasaran program pembentukan citra, Partai Keadilan Sejahtera juga dapat berkomunikasi dengan mereka dengan cara yang lebih efektif. Dalam banyak hal pemilihan segmen sasaran juga lebih memudahkan Partai Keadilan Sejahtera dalam memilih jalur yang akan dipergunakan untuk berkomunikasi dengan mereka.

Langkah kedua adalah riset publik sebagai sarana memilih kelompok sasaran. Riset dilakukan untuk mengumpulkan informasi yang bersangkutan dengan apa yang disukai dan tidak disukai publik terhadap Partai Keadilan Sejahtera sebagai organisasi politik dan kebijakan-kebijakannya. Disamping itu juga, dihasilkan informasi yang bersangkutan dengan apa yang disukai dan tidak disukai publik terhadap organisasi politik lainnya.

Setelah diketahui sejumlah informasi berdasarkan riset yang dilakukan, Partai Keadilan Sejahtera kemudian membangun relasi dengan media-media tertentu sebagai saluran informasi baru sehingga mampu menyebarkan kembali gagasan mereka kepada konstituen dan publik secara umum. Hal ini dilakukan dengan beberapa kegiatan seperti press release, press conference dan advokasi atas sejumlah kasus yang mereka alami.

Langkah ketiga adalah dengan melakukan segmentasi kelompok sasaran. Perusahaan dapat membagi kelompok sasaran utama menjadi beberapa segmen. Segmentasi sasaran ini dilakukan untuk mempermudah penyebaran informasi dalam konteks pencitraan positif mereka sehingga informasi data dikategorisasikan berdasarkan sasaran. Memberikan penerangan kepada publik melalui pendekatan komunikasi persuasif, membujuk secara langsung untuk mengubah sikap dan tindakan merupakan upaya dan langkah-langkah penting yang harus dilakukan. Dengan upaya demikian, diharapkan upaya membangun citra baik Partai Keadilan Sejahtera dapat terwujud tanpa mengalami banyak kesulitan dan mampu memperbaiki citra mereka.

\section{PENUTUP}

Konsolidasi yang dijalani PKS cukup unik, karena mengandung empat aspek. Pertama, konsolidasi ideologi yang tertuang dalam Falsafah Dasar Perjuangan, Kedua, konsolidasi politik termaktub dalam Platform Kebijakan Pembangunan PKS yang memuat langkah-langkah strategis PKS untuk memperbaiki kondisi bangsa. Ketiga, konsolidasi organisasi termuat dalam Anggaran Dasar dan Anggaran Rumah Tangga PKS, yang mengatur tertib organisasi sejak di tingkat pusat, wilayah, daerah, cabang dan ranting dan aspek keempat adalah konsolidasi 
basis massa yang belum tuntas dirumuskan PKS, karena sepanjang dua dekade pasca reformasi belum terbentuk basis sosial baru dalam perpolitikan Indonesia.

Untuk membangun kebersamaan internal, PKS mengadakan peringatan Hari Besar Islam dengan mengumpulkan beberapa pengurus, kader dan konstituen PKS. Peringatan Maulid Nabi menjadi sebuah momen tersendiri untuk membangun soliditas dan kebersamaan partai.

Konsolidasi internal partai terus dilakukan terutama menjelang Pilgub Jawa Barat Tahun 2018. Konsolidasi dilakukan sekitar di wilayah Jawa Barat, acara konsolidasi lebih sering dilakukan oleh calon Gubernur dari PKS yaitu Ahmad Syaikhu beserta Tim. Targetnya tidak ada lagi keraguan untuk memberikan dukungan untuk pemenangan pasangan calon gubernur Jawa Barat.

Saluran komunikasi internal yang dipergunakann PKS adalah dengan jalan memberlakukan sistem kaderisasi dengan berbagai jenjang, Jenjang tersebut berfungsi sebagai sarana untuk membangun komunikasi dan memilah orangorang yang disiapkan untuk ditempatkan pada posisi-posisi tertentu.

Kader dibina dan saling membina antar jenjang pembinaan, dan kontinuitas sistem ini terus dijaga guna mempertahankan soliditas antar anggota partai. Proses sosialisasi Pilgub Jabar tentunya juga dilakukan dengan model seperti ini, sehingga kecil kemungkinan kalau ada kader yang memilih calon gubernur diluar dukungan PKS.

PKS dalam Pilgub Jabar ini berupaya untuk mengangkat citra partai dengan melakukan perubahan-perubahan orientasi yang lebih terbuka dan kerakyatan tidak lagi menjadi partai ekslusif, tidak lagi memiliki icon sebagai partai kelas menengah. PKS berupaya mensejajarkan diri dengan partai lain membuka peluang dengan partai lain dan menyapa masyarakat di berbagai strata dengan pendekatan yang relevan. PKS berhasil mempertahankan suara di tengah badai lantaran faktor kaderisasi yang baik, soliditas kader, dan kinerja di lapangan.

Salah satu strategi PKS untuk memenangkan Pilgub Jabar 2018 yaitu dengan mengoptimakan komunikasi dengan daerah asal Sudrajat dan Syaikhu. Sudrajat didorong untuk lebih inten bersosialisasi di wilayah Priangan, sementara Syaikhu akan dioptimalkan di wilayah pantura.

Sebagai partai politik yang mengusung calon gubernur di Pilgub Jawa Barat tahun 2018, PKS menggunakan berbagai strategi pencitraan untuk mendapatkan kemenangan. Salah satunya adalah dengan mengerahkan seluruh anggota legislatifnya. PKS mengundang sejumlah tokoh dari luar partai untuk memberikan pandangannya terkait dinamika dan situasi politik saat ini.

Prinsip komunikasi atau kerjasama PKS dengan partai lain yaitu dengan jalan musyarokah ijabiyah albana, musyarokah artinya koalisi atau kerja sama, ijabiyah artinya pandangan positif, dan albana artinya konstruktif, dan nilai-nilai dasar dari partai PKS ini. Sebetulnya PKS membuka komunikasi seluas-luasnya. 
Partai keadilan sejahtera menerapkan kriteria calon kepala daerah yang akan diusung pada Pilkada 2018 yaitu pasangan yang terbentuk harus memiliki basis massa yang berbeda dan saling mengisi. Perbedaan basis massa harus dimiliki pasangan cagub cawagub karena luasnya wilayah Jawa Barat. Cagub cawagub yang terbentuk harus mewakili lebih dari 1 basis massa.

Strategi pencitraan yang dilakukan oleh Partai Keadilan Sejahtera di media dilakukan dengan cara membangun hubungan yang baik dengan media dan memanfaatkan media social secara tepat seperti halnya pemanfaatan E-mail, blog, media sosial ataupun Twitter.

Para politisi hendaknya membuka diri dan bekerja sama lebih erat dengan para intelektual agar terbentuk pola intelektualisasi politik yang mandiri dan kreatif. Partai politik hendaknya selalu menjalin kerja sama dengan semua pihak baik di tingkat regional maupun internasional.

\section{DAFTAR PUSTAKA}

Anugerah, dkk. (2013). Representasi Black Campaign dalam Spanduk Kampanye Pilkada Jakarta 2012. Interaksi Online, 1(3).

Aya, D. (2013). Peranan Tokoh Agama dalam Meningkatkan Partisipasi Politik Masyarakat Pada Pilkada Bupati 2010 di Kabupaten Halmahera Selatan. Jurnal Politico, 1(3).

Bainus, A. (2017). Kepemimpinan-di-jawa-barat. Diakses tanggal 15 September 2015. Retrieved from https://news.detik.com/berita-jawa-barat/d3501623/pilgub-jabar-2018-pks-target-hatrick

Basyah, M. N. (2010). Pemantapan Wawasan Kebangsaan dalam Mengsukseskan Pilkada 2011. Jurnal Mentari, 13(1).

Firman, N. (2007). Moderate Islamic Fundamentalism: Understanding the Political Thinking of the Partai Keadilan Sejahtera (PKS). Studi Islamika: Indonesian Journal For Islamic Studies, 14(3).

Fitri, dkk. (2019). Peranan Kepemimpinan Alim Ulama dalam Meningkatkan

Partisipasi Pemilih Pada Pilkada di Kota Padang Panjang. Journal Of Multidisciplinary Research and Development, 2(1).

Hamid, A. (2011). Politisasi Birokrasi dalam Pilkada Banten 2006. JLANA: Jumal Ilmu Administrasi Negara, 11(2).

Handoko, W. (2009). Isu Perempuan Sebagai Strategi Komunikasi Politik Kampanye Calon dalam Pilkada. Jurnal Yin Yang, 4(2).

Hasan, N. (2012). Islamist Party, Electoral Politics And Dawah Mobilization Among Youth: The Prosperous Justice Party (PKS) in Indonesia. Joumal Of Indonesian Islam, 6(1).

Hendrik, D. (2010). Variabel-variabel yang Mempengaruhi Rendahnnya Partisipasi Politik Masyarakat dalam Pilkada Walikota dan Wakil Walikota Padang Tahun 2008. Demokrasi: Jumal Imiah Politik Kenegaraan, 9(2). 
Khoiruddin Muchtar dan Aliyudin

Hendrik, D. (2010). Variabel-variabel yang Mempengaruhi Rendahnnya Partisipasi Politik Masyarakat dalam Pilkada Walikota dan Wakil Walikota

Padang Tahun 2008. Demokrasi: Jurnal Ilmiah Politik Kenegaraan, 9(2).

Humaedi, dkk. (2018). Resolusi Konflik Pilkada di Kota Cimahi Jawa Barat. Social Work, 8(1).

Insani, M. A. (2013). Strategi Kemenangan Pasangan Tatto Suwarto PamujiAkhmad Edy Susanto dalam Pilkada Kabupaten Cilacap Tahun 2012. Journal of Politic And Government Studies, 2(1).

Launtu, A. (2009). Analisis dan Eksistensi Politik Kandidat Walikota dalam Meyakinkan Pemilih Pada Pilkada Kota Makassar di Tinjau dari Aspek Marketing Mix. Akmen Jurnal Ilmiah, 6(2).

Marwah, dkk. (2008). Perempuan dan Pilkada Langsung. Jurnal Yin Yang, 3(1).

Masitoh, Dewi, Utomo, Susilo, Widayati, Wiwik. (2013) Fenomena Golput Pada Pilkada Pati 2011. Journal of Politic and Government Studies, 2(3).

Maula, G. A. dkk. (2013). Kemenangan Kembali Mantan Bupati Amat Antono Pada Pilkada Kabupaten Pekalongan Tahun 2011. Journal of Politic and Government Studies, 2(3).

Misrina. (2010). Metamorfosis Faksionalisme Internal Partai Golkar di Maluku Utara Pada Pilkada 2007. Jurnal Studi Pemerintaban, 1(1)

Muchtar, K. (2013). Komunikasi Politik Partai Golkar dalam Proses Sosialisasi dan Implementasi Paradigma Baru Masa Kepemipinan Aburizal Bakrie 2009 - 2013. Jurnal Penelitian Komunikasi, 16(2).

Muchtar, K. (2016). Komunikasi Politik dan Pembentukan Citra Partai. Jurnal Ilmu Komunikasi, 14(2).

Muis, A. (2009). Peran dan Fungsi DPRD dalam Pelaksanaan Pilkada Menurut Undang-Undang No. 32 Tahun 2004. Jurnal FISIP, 10(2).

Nova, F. (2011). Crisis Public Relations. Jakarta: PT Rajagrafindo Persada.

Nurdin, A. A. (2011). Democratic Experiences In Recruiting FirmanMembers And Leaders. Journal Al-Jamiah, 49(2).

Putra, I. G. N. (1999). Manajemen Hubungan Masyarakat. Yogjakarta: Universitas Atmajaya.

Siregar, S. B. (2012). Implementasi Penerapan Pilkada pada daerah Pemekaran. Jurnal Konstitusi, 1(1).

Soemirat, S., \& Ardianto, E. (2005). Dasar-Dasar Public Relations. Bandung: Remaja Rosdakarya.

Susila, A. (2009). Pilkada Kabupaten Bekasi 2007: Mengakhiri Sebuah Krisis Politik. Jurnal FISIP. 9(1).

Sutojo, S. (2004). Membangun Citra Perusahaan. Jakarta.: Damar Mulia Pustaka. Utomo, S., \& Turtiantoro. (2013). Analisis Kegagalan Partai Keadilan Sejahtera (PKS) dalam Memperebutkan Kursi di DPRD Kabupaten Batang. Journal of Politic and Government Studies, 2(2). 
Public Relations Politik Partai Keadilan Sejahtera dalam Pemilukada Jawa Barat

Wisnumurti, O dkk. (2011). Local Political Dynamics In The General Election

Directly Conducted To Vote For District Heads (Pilkada) In Badung Regency In 2005. E-Journal Of Cultural Studies, 5(2).

Zainuddin. (2009). Menyoal Peran Panitia Pengawas Pemilu dalam Pilkada. Jurnal Legalitas, 2(3). 
Khoiruddin Muchtar dan Aliyudin 